\title{
A Typology of Stakeholders and Guidelines for Engagement in Transdisciplinary, Participatory Processes
}

OPEN ACCESS

Edited by: Marianna Mea,

Ecoreach s.r.l., Italy and Jacobs University of Bremen, Germany

Reviewed by:

Sabine Pahl,

Plymouth University, UK Lyndsey Ann Dodds, WWF-UK, UK

${ }^{*}$ Correspondence: Alice Newton anewton@ualg.pt

Specialty section: This article was submitted to Marine Ecosystem Ecology, a section of the journal

Frontiers in Marine Science

Received: 20 June 2016 Accepted: 31 October 2016 Published: 16 November 2016

Citation:

Newton A and Elliott M (2016) A Typology of Stakeholders and Guidelines for Engagement in

Transdisciplinary, Participatory Processes. Front. Mar. Sci. 3:230. doi: 10.3389/fmars.2016.00230

\begin{abstract}
Alice Newton ${ }^{1,2 *}$ and Michael Elliott ${ }^{3}$
${ }^{1}$ Department of Environmental Impacts and Economics, Norwegian Institute for Air Research, Kjeller, Norway, ${ }^{2}$ Centre for Marine and Environmental Research, University of Algarve, Faro, Portugal, ${ }^{3}$ School of Environmental Sciences, Institute of Estuarine and Coastal Studies, University of Hull, Hull, UK
\end{abstract}

This paper fulfils a gap in environmental management by producing a typology of stakeholders for effective participatory processes and co-design of solutions to complex social-environmental issues and then uses this typology for a stepwise roadmap methodology for balanced and productive stakeholder engagement. Definitions are given of terminology that is frequently used interchangeably such as "stakeholders," "social actors," and "interested parties." Whilst this analysis comes from a marine perspective, it is relevant to all environments and the means of tackling environmental problems. Eleven research questions about participative processes are addressed, based on more than 30 years of experience in water, estuarine, coastal, and marine management. A stepwise roadmap, supported by illustrative tables based on case-studies, shows how a balanced stakeholder selection and real engagement may be achieved. The paper brings these together in the context of several up-to-date concepts such as complex, nested governance, the 10 tenets for integrated, successful, and sustainable marine management, the System Approach Framework and the evolution of DPSIR into DAPSI(W)R(M) framework. Examples given are based on the implementation of the Marine Strategy Framework Directive, the Water Framework Directive, the Environmental Impact Assessment Directive, the Framework Directive for Maritime Spatial Planning, as well as for Regional Sea Conventions. The paper also shows how tools that have been developed in recent projects can be put to use to implement policy and maximize the effectiveness of stakeholder participation.

Keywords: Stakeholders, transdisciplinary research, coastal and marine management, implementation of MSFD

\section{INTRODUCTION}

\section{Context and Objectives}

Successful integrated marine management requires the coordination of many aspects, from an assessment of the source, causes, and consequences of problems, the delivery of ecosystem services and societal benefits, the incorporation of governance from the local to the global, and implementing the ecosystem approach (Elliott, 2014). The success of each of these requires the input from and often agreement with the "stakeholders," defined in Section Definitions below. This paper focuses on participatory processes with examples of marine management in Europe, but the principles can be applied in other, non-European contexts and non-statutory processes. 
Initiatives deemed to be stakeholder-led, or at least with a high degree of consultation are increasing. For example, the UK Marine Conservation Zone project, which aimed at proposals for Marine Protected Areas, was required by statute to be "stakeholder-led" using local, stakeholder panels (Natural England and the Joint Nature Conservation Committee, 2012). Similarly, planning regulations involving a formal Environmental Impact Assessment, as sanctioned by the EU EIA Directive, are centered on stakeholder consultation. Elliott (2014) therefore briefly proposed a brief, initial typology of stakeholders but this needs to be further explored and refined to ensure it covers all potential bodies. Furthermore, because of the participatory process, it is valuable to assess the types of stakeholders, their role in each part of the marine management process and the influence both on the process and on them personally.

Accordingly, the aim of this paper is to provide guidelines, which can eventually be embedded into a prescriptive method, to support and develop participatory processes by using an appropriate framework for stakeholder definition and engagement. Therefore, the objectives are: (i) to further develop a typology of stakeholders; (ii) to provide guidance for appropriate and equitable stakeholder engagement; and (iii) to illustrate how this can be achieved in the implementation of marine environmental governance, such as the EU (2008) Marine Strategy Framework Directive (MSFD, 2008/56/EC). This Directive, based on a System Approach to management and participatory processes, requires that "all interested parties are given early and effective opportunities to participate in the implementation of this Directive." In turn, this gives rise to set of research questions (Box 1) that will be addressed in this paper.

\section{Definitions}

The terms social actors, stakeholders, and interested parties are used throughout environmental management, therefore it is appropriate to define these first. Sociology is a comprehensive science of social action with an analytical focus on individual human actors or social actors (Weber, 1991). This may or may not include those with a statutory remit, those who actively influence the course of social action, and/or those passively affected by others' actions rather than actively influencing the outcomes.

BOX 1 | Stakeholder-orientated research questions.

(1) What are the definitions of interested parties stakeholders and social actors?

(2) Who are the interested parties and stakeholders?

(3) What types of stakeholders are there?

(4) What are the roles of each type?

(5) Why are stakeholders important in participatory processes?

(6) What influence do/should they have in marine management?

(7) Are all stakeholders equal?

(8) What are the difficulties and conflicts?

(9) How should interested parties be involved?

(10) What examples have worked?

(11) How can we improve stakeholder participation?
There are many definitions of the term stakeholder, several of which are collected in Mehrizi et al. (2009). Using these, we suggest the following inclusive definition that is relevant in a marine management context " $a$ stakeholder is a person, organisation or group with an interest (professional or societal) or an influence on the marine environment or who is influenced directly or indirectly by activities and management decisions."

The MSFD gives a brief indication of what is meant by interested parties in that it should be: "involving, where possible, existing management bodies or structures, including Regional Sea Conventions, Scientific Advisory Bodies, and Regional Advisory Councils." However, many other "stakeholders" or "actors" would also be "interested parties" with respect to the implementation of the MSFD, if they have an interest in the outcome or an influence on the outcome. They include the many people whose livelihood and welfare depends on the sea, such as: fishers and shellfish harvesters; aquaculture farmers; offshore extractors of minerals such as oil, gas, sand, and gravel; offshore wind farms, tidal and wave energy; coastal, cruise, and eco-tourism developers; and maritime transport. This also includes the millions of people who choose "sun, beach, and sand" vacations (Semeoshenkova and Newton, 2015). For the purposes of this paper, the term "stakeholder" has thus been adopted as an inclusive term that also incorporates the various interested parties and social actors. This makes it necessary to have some clear definitions and a typology that covers the roles of stakeholders, both of which are provided in this paper.

\section{WHO ARE THE INTERESTED PARTIES, STAKEHOLDERS AND SOCIAL ACTORS?}

\section{Interested Parties}

The MSFD aims to ensure that EU Member States can achieve Good Environmental Status in their seas by 2020 according to a set of 11 descriptors which encompass and affect all the uses and users of the seas (Borja et al., 2013). Hence, by definition, the detection and achievement of GES has to be a stakeholderled process in order to achieve successful and sustainable marine management. Correctly identifying the stakeholders is fundamental to participatory processes (WMO, 2006). The “interested parties" referred to in the MSFD (Table 1) include the four European Regional Sea Conventions and the seven fisheries Regional Advisory Councils. The MSFD focus therefore seems to be limited to fisheries as the main economic sector, and thus, by not specifically indicating other stakeholders, it is not as inclusive as intended. Examples of possible Scientific Advisory Bodies are also listed. Previously (Elliott, 2014), we considered that the pressures affecting the marine environment emanate from three sources-materials (including infrastructure) put into the seas, materials, and space/habitat removed from the seas, and external factors such as climate change. Each of these has its own interested parties, although of course there is extensive overlap between them. In Table 1, the interested parties encompass the users, those controlling the users and those 
TABLE 1 | Interested parties referred to in the Marine Strategy Framework Directive.

\begin{tabular}{|c|c|c|}
\hline European Regional Sea Conventions (RSC) & Regional Advisory Councils (RAC) & $\begin{array}{l}\text { Examples of possible Scientific Advisory } \\
\text { Bodies }\end{array}$ \\
\hline The Convention for the Protection of the Marine Environment in the & North Sea RAC & International Council for the Exploration of the \\
\hline \multirow{3}{*}{$\begin{array}{l}\text { North-East Atlantic of } 1992 \text { (further to earlier versions of } 1972 \text { and } \\
\text { 1974)-the OSPAR Convention (OSPAR) }\end{array}$} & North Western Waters & Sea (ICES) \\
\hline & RAC South Western Waters & ASCOBANS \\
\hline & RAC The Pelagic Advisory Council & ACCOBAMS \\
\hline $\begin{array}{l}\text { The Convention on the Protection of the Marine Environment in the Baltic } \\
\text { Sea Area of } 1992 \text { (further to the earlier version of 1974) - the Helsinki } \\
\text { Convention (HELCOM) }\end{array}$ & Baltic Sea RAC & $\begin{array}{l}\text { European research on ocean Ecosystems } \\
\text { under Anthropogenic and Natural forcings } \\
\text { (EUROCEANS) }\end{array}$ \\
\hline The Convention for the Protection of Marine Environment and the Coastal & Mediterranean Sea RAC & European Marine Board \\
\hline Region of the Mediterranean of 1995 (further to the earlier version & & Seas at Risk \\
\hline of 1976) - the Barcelona Convention (UNEP-MAP) & & UNEP \\
\hline $\begin{array}{l}\text { The Convention for the Protection of the Black Sea of 1992-the Bucharest } \\
\text { Convention }\end{array}$ & & FAO \\
\hline \multirow[t]{2}{*}{ United Nations Convention on the Law of the Sea (UNCLOS) } & The Long Distance Advisory Council & IOC \\
\hline & & $\mathrm{IMO}$ \\
\hline Convention on Biological Diversity (CBD) & & UNDP \\
\hline \multirow[t]{3}{*}{ Convention on Migratory Species (CMS) } & & OCEANA \\
\hline & & IUCN \\
\hline & & WWF International \\
\hline
\end{tabular}

affected by or benefitting from the uses. This underlines the need to develop both a typology and a methodology that promotes balanced participation and stimulates meaningful rather than perfunctory engagement. Ideally, this should ensure that the relevant interested parties, stakeholders, and social actors are invited to be involved in a participatory process and that each is aware of the roles of the others, even though this may be difficult to achieve.

\section{What Types of Stakeholders Are There and What Are Their Roles?}

A typology that encompasses all the types of stakeholders is proposed in Table 2 and has resulted from many years of experience in water, estuarine, coastal and marine management as well as considering and discussing the need for, and role of stakeholders. Successful and sustainable solutions to marine problems range across the so-called 10-tenets that encompass technical, economic, governance, and societal aspects (Elliott, 2013; Barnard and Elliott, 2015), and the proposed typology embraces these. The typology includes six types of stakeholders that have been developed from those in Elliott (2014) and are not dissimilar to those proposed by Lovens et al. (2014). The links to the source, causes and consequences of human activities in the sea use the DAPSI(W)R(M) framework (Patrício et al., 2016; Scharin et al., 2016) in which Drivers (the basic human needs, the individual and societal aspirations) require Activities (by the users, developers, industries, etc.) that in turn create Pressures, which are the mechanisms to cause adverse State changes to the natural (physical, chemical, and biological) environment. If left unchecked, these create an Impact (on human Welfare) that need to be addressed by Responses (involving Measures).

Those creating the pressures in the sea are the "inputters" (of pollution, infrastructure, sediment, etc.) and "extractors" (of fish, water, space) who then are regulated by the "regulators," those statutory bodies with a legislative competency, supported by administrative bodies and given that competency by a very large number of legal instruments (e.g., Boyes and Elliott, 2014, 2015). Those who take or receive advantage of those uses and materials provided by the seas or even who get advantage by reducing their costs due to putting wastes into the seas, are termed "beneficiaries," a group that contains most if not all of society. Next, there is a large group of stakeholders that are affected, possibly adversely, by those using and managing the seas, for want of a better term and in keeping with the labels for the other types these are called "affectees." Finally, there are the "influencers," those politicians, non-governmental organizations, media, academics, and educators who play a part in directing the nature of marine use.

Some stakeholders have a very precise role and this typology. For example, an Environmental Protection Agency or Nature Conservation Agency is a statutory regulator in a defined area of competence, (in this case, water quality and species protection, respectively). However, they may be an "influencer" for topics outside their own jurisdiction and are often a statutory or nonstatutory consultee when other bodies are faced with decisions. In contrast, stakeholders often play a role in more than one of these groups, given that the role of the stakeholder depends on the context and issue. For example, fishers extract a resource and input materials and infrastructure, such as discards, waste, 
TABLE 2 | Typology and roles of stakeholders with some illustrative examples.

\begin{tabular}{|c|c|c|}
\hline Type & Definition/Role & Examples \\
\hline "Extractors" Drivers, activities, and pressures & $\begin{array}{l}\text { Those using space or taking biotic and abiotic } \\
\text { resources from the marine system }\end{array}$ & $\begin{array}{l}\text { Fishers, aggregate extractors, space } \\
\text { occupiers, or removers (by habitat loss), water } \\
\text { abstractors, salt extractors, etc. }\end{array}$ \\
\hline
\end{tabular}
$\begin{array}{ll}\text { "Inputters" Drivers, activities, and pressures } & \begin{array}{l}\text { Those discharging or placing materials or } \\ \text { infrastructure into the marine system }\end{array}\end{array}$
Builders of infrastructure, pollutant dischargers, industries, fishing discards, thermal discharges from power plant cooling water, ballast water discharges introducing non-indigenous species

\begin{tabular}{ll}
\hline "Beneficiaries" (of Ecosystem services, of the & $\begin{array}{l}\text { Those benefitting from the ecosystem services } \\
\text { and goods created by the system and } \\
\text { delivered by the users }\end{array}$ \\
& $\begin{array}{l}\text { Howeviety, all other relevant stakeholders. } \\
\text { cheapest option of discharging waste may also } \\
\text { be a beneficiary. }\end{array}$
\end{tabular}

"Affectees" (by Impact on human welfare)

Those affected by the uses and users, affected

by the policy decisions, impacted by the

decisions whether positive or negative

Society, all other relevant stakeholders, NGO's

Externalities, those who incur costs rather than acquire benefits

"Regulators" Responders (using Measures) of society

Those giving permission to occupy space or extract/input materials, those with a controlling role on the users of the system; "hard" and "soft" regulators

"Influencers" Represent or are concerned about the State of the environment and ecosystem
Government Administrative, legislative bodies, international policy makers, national and European legislators, statutory bodies Those influencing policy and use/users
Expert groups, NGOs, lobby groups (WWF/RSPB), scientists, educators, public

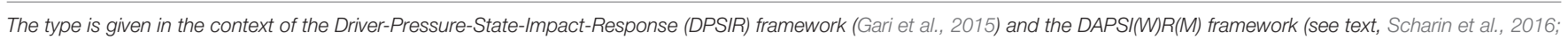
Patrício et al., 2016).

garbage, and harbors. They are beneficiaries of the ecosystem provisioning services. They are also affected by other fishers, as well as many other users of the seas, for example the installation of offshore wind farms. They collectively are policy-influencers with strong lobbies and a presence on advisory bodies (such as the National Federation of Fishermen's Organizations in the UK) and they may have a role in the local governance of the activity.

An example of the typology of stakeholders for two Good Environmental Status Descriptors of the MSFD is given in Table 3 and an indicative list of stakeholders for the UK sector of the North Sea is given in four to show the breadth of bodies involved. General (civil) society is additional to this list.

\section{Why Are Stakeholders Important in Participatory Processes?}

Stakeholder engagement and involvement is the basis of a participatory process and is fundamental to acceptance of management actions and by definition the process is not participatory if stakeholders are not involved. Community-based, adaptive management requires stakeholder engagement and participation from the early planning stage. Stakeholders gain a better understanding of issues and conflicts through participation in the co-design and co-development of the management plan. The process can provide an opportunity for conflict resolution and also increases the ownership, ease of acceptance and uptake of jointly designed solutions. Under the governance principle of subsidiarity, a cornerstone of the European Union, key management decisions should be made as close to the scene of events and the actors involved for the sustainable management of socio-ecological systems and their resources (Ostrom, 2009). Governments therefore strive to engage stakeholders to influence policy and to reach a consensus for sustainable management. There are several examples in which a range of stakeholders is required to be consulted and, in the case of Environmental Impact Assessments, it is often legally required (Glasson et al., 2011).

Finally, stakeholders have an important role in checking whether the outcome of the adaptive management process (e.g., responses of governance, regulations, recommendations, programme of measures, management plans) conform to the 10-tenets proposed by (Elliott, 2013). These require management actions to be Ecologically sustainable, Technologically feasible, Economically viable, Socially desirable/tolerable, Legally permissible, Administratively achievable, Politically expedient, Ethically defensible (morally correct), Culturally inclusive, and Effectively communicable. These facets, if achieved, should cover all parts of the decision-making process and thus, by engaging stakeholders in decision-making, should provide for a sustainable and accepted, consensual solution. It should allow contentious issues to be raised, defined and resolved early on in the process, and thus be used to minimize conflicts. Nevertheless, there is a paradox of stakeholder consensus in reaching a stakeholder-led decision, whereby stakeholder panels may agree collectively on the lowest common denominator, i.e., the least painful solution for each of them. 
TABLE 3 | Example of typology of MSFD stakeholders for Good Environmental Status Descriptor 3 (commercial species) and Descriptor 5 (eutrophication).

\begin{tabular}{|c|c|c|}
\hline Type & D3 commercial species & D5 eutrophication \\
\hline Extractors & Fishers, shellfish harvesters & Fishers, Shellfish harvesters, aquaculture \\
\hline \multirow[t]{3}{*}{ "Inputters" } & Industry: Industrial contaminants & Industry: organic matter (food, paper industry) and fertilizer industry \\
\hline & Municipalities: Pathogens in sewage & Municipalities: organic matter and phosphorus in sewage effluent \\
\hline & $\begin{array}{l}\text { Shipping: NIS from ballast water Fishers: from } \\
\text { discards and fish/shellfish waste }\end{array}$ & Agriculture: fertilizers and manure \\
\hline \multirow[t]{4}{*}{ Beneficiaries (Ecological services) } & Society: abundant, safe seafood & $\begin{array}{l}\text { Society: abundant, safe seafood and aesthetically-pleasing areas; } \\
\text { economically-beneficial areas from real estate prices }\end{array}$ \\
\hline & Fishers: sustainable catch & Fishers: sustainable catch Shellfish harvesters: sustainable harvest \\
\hline & Shellfish harvesters: sustainable harvest & Aquaculture: low losses from Hypoxia or Harmful Algal Blooms \\
\hline & $\begin{array}{l}\text { Tourism and leisure: diving, sport fishing, } \\
\text { ecotourism }\end{array}$ & Tourism: clear water, no smells \\
\hline \multirow[t]{5}{*}{$\begin{array}{l}\text { "Affectees" (Impact on human welfare, } \\
\text { sometimes represented by NGOs) }\end{array}$} & $\begin{array}{l}\text { Fishers and Shellfish harvesters: Economic } \\
\text { loss, poor catches (quantity and value) } \\
\text { Employment loss, job security is threatened }\end{array}$ & $\begin{array}{l}\text { Fishers, Shellfish harvesters and aquaculture: Economic loss, poor catches } \\
\text { (quantity and value), job security is threatened. }\end{array}$ \\
\hline & $\begin{array}{l}\text { Secondary employments: e.g., food } \\
\text { processing, jobs threatened }\end{array}$ & Secondary employments: e.g., food processing, jobs threatened \\
\hline & $\begin{array}{l}\text { Society: Cultural identity and traditions of } \\
\text { fishing community is threatened }\end{array}$ & $\begin{array}{l}\text { Tourism: loss of revenue and jobs due to loss of clean beaches and clear } \\
\text { waters }\end{array}$ \\
\hline & Increased cost of seafood to society & $\begin{array}{l}\text { Society: Public Health risk from HABs and pathogens, economic results of } \\
\text { environmental degradation }\end{array}$ \\
\hline & & $\begin{array}{l}\text { Cultural identity and traditions of community is threatened, Increased cost of } \\
\text { seafood to society }\end{array}$ \\
\hline Regulators & $\begin{array}{l}\text { Fishery regulator bodies, Government } \\
\text { Administrative, legislative bodies, international } \\
\text { policy makers, national and European } \\
\text { legislators, statutory bodies, RSC }\end{array}$ & $\begin{array}{l}\text { Public Health authorities, Government Administrative, legislative bodies, } \\
\text { international policy makers, national and European legislators, statutory } \\
\text { bodies, RSC }\end{array}$ \\
\hline Influencers & $\begin{array}{l}\text { Government, politicians, stakeholder } \\
\text { consultation groups, expert groups, NGOs, } \\
\text { lobby groups, scientists, educators }\end{array}$ & $\begin{array}{l}\text { Government, politicians, stakeholder consultation groups, expert groups, } \\
\text { NGOs, lobby groups, scientists, educators }\end{array}$ \\
\hline
\end{tabular}

The listing is general not specific, e.g., RSC is given instead of OSPAR, HELCOM, Mediterranean, and Black Sea Conventions.

As an example of this, the recent Marine Conservation Zone projects in the UK, in response to government demands for a stakeholder-led process, set up regional stakeholder panels that each aimed to have one representative of each main sector within the region (Jones, 2012). Their role was to use the Ecological Network Guidance provided by the statutory nature conservation bodies in designing and positioning Marine Conservation Zones, (Natural England and the Joint Nature Conservation Committee, 2012). Within such a stakeholder panel for a geographical area, a stakeholder who is a fishing representative is unlikely to agree to site a Marine Protected Area in a fishing area where fishing will be limited. An aggregate (sand and gravel) extractor may agree to site an MPA in areas away from the extractors favored resource. Hence, the stakeholders may all agree to site a Marine Protected Area in a location no one wants for any other purpose, i.e., an area unsuitable for fishing, aggregate extraction, offshore wind, etc. Should this hypothetical example be approved, the regulators could claim that a stakeholder-led solution was reached, but this was only achieved by designating a conservation-poor area.

\section{SOCIAL EQUITY: ARE ALL STAKEHOLDERS EQUAL?}

Some stakeholders are more relevant to particular issues than others. Relevant stakeholders for one issue may be of little or no importance for another issue. For example, while NGOs may encourage developers to create an ecologically sustainable option, the shareholders of the developer are more likely to be responsive to the consequences of statutory regulators threatening legal action with financial penalties or the size of a resource to be exploited. The relevance of a stakeholder in one of the type categories in Table 2 (and the examples for each type in Table 4) thus depends on the issue, for example the MSFD descriptor that is being addressed. For example, in the case of the general implementation of the Marine Strategy Framework Directive, the participation of the competent authorities of the Member States and the Regional Seas Commissions are not just desirable but paramount. If only one particular descriptor is being addressed, then representatives of economic sectors that are significant should definitely be included. A semi-quantitative example of 
TABLE 4 | List of Marine Stakeholders-Example for the UK Sector of the North Sea (D Burdon, IECS University of Hull, pers. com).

\begin{tabular}{ll}
\hline Type & Organization \\
\hline International/European & OSPAR \\
& EU DG MARE \\
& International Maritime Organization (IMO) \\
& EU DG Transport \\
& International Council for the Exploration of the Sea \\
& (ICES)
\end{tabular}

\begin{tabular}{ll}
\hline Policy-making body & Marine Management Organization \\
& Department of Environment, Food and Rural Affairs \\
& (Defra) - nature conservation \\
& Department of Energy and Climate Change (DECC) \\
& DISS \\
& Marine Scotland \\
& Joint Nature Conservation Committee \\
& Defra-environmental protection \\
& Defra-fisheries \\
\hline
\end{tabular}

\begin{tabular}{ll}
\hline Statutory body/ & Environment Agency \\
Competent authority & Natural England \\
& Scottish Natural Heritage \\
& East Riding Yorkshire Council \\
& Associated British Ports (ABP; port authority) \\
& North-Eastern Inshore Fisheries and conservation \\
& Agency (IFCA) \\
& Scottish Environmental Protection Agency
\end{tabular}

Commercial user Fishing Coalition/National Federation of Fishermen's Federation Organization (NFFO; fishing)

British Marine Aggregate Producers Association (BMAPA; aggregates)

PIANC (dredging/navigation)

British Board of Shipping (shipping)

UKOOA (oil and gas)

UK Renewables (offshore energy)

ABP (ports/harbor)

Seabed User group

EDF (coastal power plants)

Shellfish producers

Scottish and Southern Electricity (SSE) - gas storage

\begin{tabular}{ll}
\hline NGO/Public & World-wide Fund for Nature (WWF) \\
& Royal Society for the Protection of Birds (RSPB) \\
& Marine Conservation Society \\
& Whale and Dolphin Conservation Society \\
& Royal Yachting Association \\
& Net Gain Marine Conservation Zone (MCZ) project \\
& Balanced Seas MCZ project \\
& Recreational Fishing Societies \\
& Cefas (research) \\
IECS (research/consultancy/education) \\
University Academic/Consultant \\
University Academic/Consultant \\
University Academic/Consultant
\end{tabular}

how the weightings of stakeholders may be employed and differ for different issues is shown in Table 5. The weightings serve to emphasize important stakeholders to be recruited. This compares an environmental quality issue (eutrophication) with a resource exploitation one (fishing). Both of these have a set of social actors/stakeholders causing the problem as well as those being affected by it socially and economically and those trying to regulate it. The relative weightings will vary, not only according to the societal or business repercussions on the stakeholder in question, but also the prevailing environmental and societal conditions. For example, under economically difficult times, as over the past decade, the financial and economic imperatives may be prioritized (Borja and Elliott, 2013). Nevertheless, each stakeholder may project a different weighting either through forceful argument (the problem of "he who shouts loudest"), or a self-assumed weighting, giving the impression that a stakeholder is considered more important than others. For example, in maritime countries where fishing was historically more important than today, the fishing lobby may assume an exaggerated importance (the boxing analogy of "punching above their weight"!).

An experienced moderator is essential for the success of a participatory process. Ideally, a stakeholder panel should represent all relevant stakeholders in a fair and balanced manner. It is assumed that if all stakeholders are consulted, then a balanced outcome should be guaranteed but of course, this is not always the case. Similarly, while it is hoped that all stakeholders should have an objective and rational view, it is perhaps better to assume that they are all defending their own interests, and hence cancel each other out.

\section{WHAT ARE THE DIFFICULTIES AND CONFLICTS AND HOW CAN THEY BE RESOLVED?}

In addition to the tendency of reaching the lowest common denominator, a participatory process may be hampered by other difficulties, for example: (i) the misinterpretation of scientific guidelines and information by a non-scientific body, and (ii) bypassing the process. The second can arise, for example, if the main fishing lobby decides not to take part in the stakeholder process but, once the panels have finished deliberating, they petition the government minister directly, thus by-passing the process. The minister (regulator) then must decide whether to ignore the views of all the other stakeholders in favor of one stakeholder that is perceived (by itself) to be the most important. This would be regarded by the remaining stakeholders as circumventing the democratic process.

In addition to these difficulties, there are often conflicts between the stakeholders, based on the activities for which they may be responsible or have an involvement. A clear understanding of the nature of these conflicts is important for both the mediator and the stakeholders to better consider the various aspects of an issue and the resulting points of view. The use of a conflict matrix approach can avoid problems, reduce conflicts between stakeholders and encompass all bodies. The 
TABLE 5 | Example weightings (0 low-3 high) of different stakeholders for two MSFD Good Environmental Status Descriptors (D3 commercial species and D5 eutrophication).

\begin{tabular}{|c|c|c|}
\hline Stakeholder & D3 & DE \\
\hline Fishers & 3 & 1 \\
\hline \multicolumn{3}{|l|}{-Sustainable catch and livelihoods } \\
\hline \multicolumn{3}{|l|}{-Economic loss, poor catches (quantity and value) } \\
\hline \multicolumn{3}{|l|}{-Employment loss, job security is threatened } \\
\hline Shellfish harvesters & 3 & 3 \\
\hline \multicolumn{3}{|l|}{-Sustainable harvest and livelihoods } \\
\hline \multicolumn{3}{|l|}{-Economic loss, poor catches (quantity and value) } \\
\hline \multicolumn{3}{|l|}{-Employment loss, job security is threatened } \\
\hline Aquaculture & 3 & 3 \\
\hline \multicolumn{3}{|l|}{-Low losses from Hypoxia or Harmful Algal Blooms (HABs) } \\
\hline \multicolumn{3}{|l|}{-Employment loss, job security is threatened } \\
\hline Secondary employments: e.g., food processing, jobs threatened & 3 & 3 \\
\hline Industry: industrial contaminants (e.g., metals, PCB) & 3 & 0 \\
\hline $\begin{array}{l}\text { Industry: organic matter (food, paper industry) and fertilizer } \\
\text { industry }\end{array}$ & 0 & 3 \\
\hline Shipping: Non-Indigenous Species from ballast water & 2 & 2 \\
\hline $\begin{array}{l}\text { Municipalities: Pathogens in sewage, organic matter, and } \\
\text { phosphorus in sewage effluent }\end{array}$ & 0 & \\
\hline Agriculture: fertilizers and manure & 0 & \\
\hline Society: abundant, safe seafood & 3 & \\
\hline \multicolumn{3}{|l|}{ Increased cost of seafood to society } \\
\hline Society: Influence of aesthetic and human well-being aspects & 1 & 3 \\
\hline $\begin{array}{l}\text { Tourism and leisure: diving, sport fishing, ecotourism clear water, } \\
\text { no smells }\end{array}$ & 1 & 3 \\
\hline \multicolumn{3}{|l|}{ Employment loss, job security is threatened } \\
\hline $\begin{array}{l}\text { Society: Cultural identity and traditions of fishing community is } \\
\text { threatened }\end{array}$ & 3 & 0 \\
\hline Public Health authorities (harmful algal blooms and pathogens) & 1 & 3 \\
\hline Fishery regulator bodies & 3 & \\
\hline Government Administrative & 2 & 2 \\
\hline Government public information & 2 & 2 \\
\hline Legislative bodies, national, and European legislators & 3 & 3 \\
\hline International policy makers & 3 & 3 \\
\hline Statutory bodies & 3 & 3 \\
\hline RSC & 3 & 3 \\
\hline Politicians & 2 & 2 \\
\hline Stakeholder consultation groups & 3 & 3 \\
\hline Expert groups & 3 & 3 \\
\hline NGOs & 1 & 1 \\
\hline Lobby groups & 1 & 1 \\
\hline Scientists and researchers & 1 & 1 \\
\hline Educators & 1 & 1 \\
\hline
\end{tabular}

INTERREG project TIDE (see http://www.tide-toolbox.eu) used conflict matrix analysis and stakeholder focus groups followed by multivariate analysis to determine use and user conflicts for a set of North Sea estuaries (the Scheldt (Belgium/Netherlands), Humber (UK), Elbe (Germany), and Weser (Germany). The results in Table 6 show the links and conflicts between the different activities and their proponents, with a view to determining the priorities for resolving conflicts, either real or imagined. For example, Conservation by protection of an area was viewed by some stakeholders to be negative because access to the area was restricted.

In the marine arena, common problems requiring to be resolved by stakeholder participation include spatial conflicts, such as the access to fishing grounds being limited by offshore development of aquaculture, mineral and oil extraction, and wind farms. These are the topic of the Framework Directive for Maritime Spatial Planning, (2014/89/EU). There are frequent conflicts between types of stakeholders, such as conservationists (influencers) and fishers (extractors), especially for high value species such as blue fin tuna, or to avoid the bycatch of turtles and cetaceans. The most frequent conflicts arise between beneficiaries and the affected (winners and losers). One solution is to use tradeoffs, for instance building a longer road around a protected area rather than through it. These require a thorough cost-benefit analysis that also examines externalities and a developer or member state could cite economic constraints as a reason for not carrying out stakeholder wishes. If successful, however, mutually and stakeholder-led agreement of co-location of activities can help to reduce stakeholder conflicts (Christie et al., 2014).

Conflicts of responsibilities can also occur, for example between the EU and RSCs, (Cinnirella et al., 2014) and between $\mathrm{EU}$ and non-EU countries, for example the issues in the Black Sea arising from the Crimea crisis in 2014. The plethora of marine legislation and administrative bodies implementing these has the potential to increase confusion (e.g., Boyes and Elliott, 2014, 2015). For example, the EU Water Framework Directive requires an assessment of Good Ecological Status to $1 \mathrm{~nm}$ from the coastal baseline, the Habitats Directive requires Favorable Conservation Status in designated areas, and the Marine Strategy Framework Directive requires Good Environmental Status from the HW mark outwards to the $200 \mathrm{~nm}$ line (Boyes et al., 2016). These Directives all rely on stakeholder discussion and agreement thus requiring stakeholders, who are often the same group of individuals, to be familiar with the legislation and their implementation, the differing ecological principles and the science base, and the geographical overlap. This is rarely the case, especially as different organizations meet with different stakeholders and implement different legislation (Boyes and Elliott, 2015). Conflicts of responsibilities arise, even though each legal instrument is designed for a particular role. Thus, there are conflicts between both instruments and bodies that require to be solved by stakeholder involvement. Furthermore, when the same stakeholders are consulted regarding multiple developments from many agencies then "stakeholder-fatigue" can occur. The interest of the stakeholders may wane if they feel that their opinions are not being heard or taken seriously. An experienced moderator will ensure that the opinion of all participants is sought, heard, and treated with due respect.

A stakeholder and governance mapping step is important, based on the issue and the geographical context. Next, stakeholders are approached during the consultation phase called scoping, but it is important not to raise their expectations of being able to direct the result. They also may be confused regarding the scoping and their precise and legally defined role that includes checking, consulting, challenging, and championing. So, 
TABLE 6 | Example of results from Conflict Matrix Analysis showing the strong negative and positive associations between uses/users for North Sea estuaries.

\begin{tabular}{|c|c|c|c|}
\hline \multicolumn{2}{|r|}{ Impact of } & \multicolumn{2}{|r|}{ Impact on } \\
\hline Category & Activity & Category & Activity \\
\hline \multicolumn{4}{|l|}{ NEGATIVE } \\
\hline Conservation & Protected subtidal area & Navigation & Capital dredging \\
\hline Conservation & Protected subtidal area & Navigation & Maintenance dredging \\
\hline Conservation & Protected intertidal area & Access & Recreational access on the banks and intertidal \\
\hline Access & Recreational access on the banks and intertidal & Conservation & Protected intertidal area \\
\hline Flood/Coast protection & Flood bank (dyke/gabion/wall) & Conservation & Protected intertidal area \\
\hline Navigation & Capital dredging & Conservation & Protected subtidal area \\
\hline Navigation & Capital dredging & Conservation & Protected intertidal area \\
\hline Navigation & Maintenance dredging & Conservation & Protected subtidal area \\
\hline \multicolumn{4}{|l|}{ POSITIVE } \\
\hline Conservation & Protected subtidal area & Conservation & Protected intertidal area \\
\hline Conservation & Protected intertidal area & Conservation & Protected subtidal area \\
\hline Flood/Coast protection & Flood bank (dyke/gabion/wall) & Ports and harbours & Port related activity adjacent to system \\
\hline Flood/Coast protection & Flood bank (dyke/gabion/wall) & Industry & Industrial activity adjacent to system \\
\hline Flood/Coast protection & Flood bank (dyke/gabion/wall) & Residential & Housing adjacent to system \\
\hline Navigation & Channel stabilization & Navigation & Vessel movement \\
\hline Navigation & Capital dredging & Navigation & Vessel movement \\
\hline Navigation & Maintenance dredging & Navigation & Vessel movement \\
\hline
\end{tabular}

Those in bold are the strongest noted. (from http://www.tide-toolbox.eu).

it is important to clarify that, by statute or accepted practice, stakeholders are deemed to have a role, or at least be given the opportunity to have a role, in all stages of adaptive management. Usually, the remit is in the planning stage, and then further during each part of the assessment and writing the final report, for example the Environmental Statement (EU EIA Directive 2011/92/EU; 2014/52/EU). Finally, it is important to keep the stakeholders interested and involved in the process but not to over-burden them, again which results in stakeholder fatigue.

Conflicts of responsibilities require stakeholders to have the capacity to take such decisions. These difficulties and conflicts can result in an increasing severity of impediments to achieving sustainable marine management. Increasing severity is shown in Box 2: the first column lists "bottlenecks" or minor impediments, which do not require much effort to clear; the second column lists "showstoppers," which require a moderate focus to remove; and the third column includes "train wrecks," which potentially stop everything. Poor scientific understanding (column 1) may be overcome in the stakeholder forum through interaction with the scientists (see Issue Definition in 6a). For example, stakeholders may know that the water quality is poor, but they may have misunderstood the reason why. They may blame point sources, such as the effluent from a very effective waste water treatment plant rather than diffuse sources such as agricultural run-off. However, poor knowledge (column 2) can only be overcome by obtaining more, fit-for-purpose information and using this in an appropriate assessment, but this may not be possible because of lack of funding (Column 3). In the point-source vs. diffuse runoff example, only data from well-designed monitoring will allow the contribution of each source (point or diffuse) to be attributed.
Conflicts are frequent, so there are several available tools that can be used by a skilled mediator to defuse and attenuate them. It is not in the scope of this article to review the many available tools, but as an illustrative example, the SPICOSA project developed the kercoast deliberation-support tool http:// www.spicosa.eu/kercoast/main.htm. This is based on a matrix of stakeholders verus issues and uses a color code of red for "unacceptable," to yellow "maybe," to green "OK." The mediator starts exploring why the green issues are all $\mathrm{OK}$, to build a common understanding between the stakeholders and open the dialogue. Once this has been achieved, the yellow issues are discussed to explore whether these can be made more acceptable and changed to green. Once mutual trust has been built and the stakeholders are more aware of the other points of view, then the more difficult "red" issues can be tackled.

\section{WHAT EXAMPLES HAVE WORKED}

A good example of stakeholder engagement in developing and implementing Marine Management is the process by which the Norwegian environment agency developed the management plans for the Barents Sea, the Norwegian Sea, the North Sea and Kattegat. The Norwegian environment agency built a very broad stakeholder forum for the design of the management plans. These were then open to public consultation, debated in Parliament and adopted. When several Member States or contracting parties are involved, consensus, and implementation may be difficult if the process is not planned and executed in a timely manner. Another good example involving several countries is the Common Implementation Strategy (CIS) of the 
BOX 2 | Examples of "bottlenecks," "showstoppers," and "trainwrecks" in marine management.

\begin{tabular}{|c|c|c|}
\hline Bottlenecks & Showstoppers & Trainwrecks \\
\hline Lack of clear objectives & Complex regulation & Intransigence \\
\hline No stakeholder forum & Poor knowledge & Lack of funding \\
\hline Poor scientific understanding & Poor training & Legal challenges \\
\hline Poor advice & Overlapping designation & Political will \\
\hline Confusing planning system & Conflicting designation & Unwillingness to adopt joint aims/vision \\
\hline Manageable hazards & Sectoral management & Inflexible planning system \\
\hline \multirow[t]{8}{*}{ Poor communication } & Poor administration & Unmanageable hazards \\
\hline & Economic prerogative & Lack of permissions \\
\hline & Lack of technologies & Cultural conflicts \\
\hline & Lack of tools & Iconic ecology \\
\hline & Increasing governance & Ethically immoral \\
\hline & Slow planning system & \\
\hline & Non-integrated planning system & \\
\hline & Manageable hazards & \\
\hline
\end{tabular}

Water Framework Directive (WFD) for coastal waters, which included an inter-calibration process (Goela et al., 2009). This was specifically designed so that neighboring Member States would reach similar results in the assessment of transboundary waters.

\section{A ROAD-MAP FOR IMPROVING STAKEHOLDER INVOLVEMENT AND PARTICIPATORY PROCESSES}

Integrated marine management involving stakeholders can be regarded as consisting of four steps-integration, adaptation, participation, and collaboration (Figure 1, adapted from Carvalho and Fidélis, 2013). Stakeholders play a key role in each of these steps and indeed drive those steps through the engagement and participatory process. In turn, there are several existing and useful guidelines for stakeholder engagement in participatory processes, (e.g., Fish et al., 2011; Durham et al., 2014) and so here we set out a road-map for participatory processes and useful stakeholder engagement. The road-map includes simple steps, processes and checklists to navigate through participatory processes. It is derived from earlier examples bringing together tried and tested features from many experiences in different countries, continents and contexts, estuarine, coastal and marine. There are no panaceas, and any method should be locally adapted, but we suggest the following steps, giving examples to clarify as necessary.

\section{Issue Definition}

It is axiomatic that if society perceives a problem, then by definition, there is a problem to be tackled. For example, stakeholders may report "bad water quality," but this can be due to a plethora of issues such as industrial contamination, or just sewage effluent or, in the case of the general public, if they see turbid waters there may be a perception of poor quality, irrespective of the scientific evidence. Scientists working with the authorities and the stakeholders can help to better define the issue and this will help to better identify the system (6b) most the relevant stakeholders (6c).

\section{System Definition}

This step defines "who is in and who is out." For example, is Austria a relevant stakeholder in the MSFD? It may be a minor actor since the Danube flows to the Black Sea. Sometimes, given the extensive connectivity that governs marine and coastal processes, relevant stakeholders may be half a continent away, or even further, contributing to the idea of "unbounded boundaries" in marine systems. An example are the Iowa farmers who input fertilizers into the Mississippi, contributing to the eutrophication and the Dead Zone of the Gulf of Mexico (Rabalais et al., 2002). This is also the case for the atmospheric deposition of long-range pollutants, such as mercury (Pacyna et al., 2006) and Persistent Organic Pollutants (POPs; Bidleman et al., 1990).

\section{Stakeholder and Governance Mapping}

Once the issue (6a) and the system (6b) have been defined, the mapping of the stakeholders and governance can proceed. For example, in the case of eutrophication (Descriptor 5 of the MSFD), food processing, paper mills, municipalities, farmers, the fertilizer industry, and animal rearers, including aquaculture, are possible stakeholders, some of whom may be irrelevant for another descriptor, such as Descriptor 11, Energy, and Noise. The categories and types of stakeholders are identified to be potentially involved in the decision making process. This is to better understand the stakeholder landscape and is a worthwhile process (see Morris, 2012). The mapping defines the possible participants, consistent with the proposed typology (Table 2), that are relevant (Table 3) to the issue and system. The mapping should include representatives of relevant economic sectors (extractors and inputters, externalities), and also include relevant influencers (e.g., NGOS, scientists, activitists, media). The governance mapping defines who can act (regulators) on any recommendations, such as decision makers, policy makers, managers at all geographical scales, local, national, regional (sea), European.

The objective is to achieve a representative cross-section of relevant stakeholders. Once more an experienced moderatorfacilitator is useful at this stage of selection, so that the process remains inclusive and balanced. Opinions about who the 


\section{Integration:}

Of the water resources (inland, transitional, coastal and marine) and hydrological, geochemical and biological cycles, structure and functioning;

Of ecosystems (aquatic \& terrestrial) \& of socioeconomic and of socio-ecological systems; Of scientific, technical and local (empirical and theoretical (deterministic)) knowledge;

Of the various sector policies that interact with water policy;

Of the different levels of institutional governance (global, national, regional \& local);

Of the bodies (public, private \& non-profit) \&

stakeholders involved in decision-making.

\section{Adaptation:}

Ensuring adaptation to risk and uncertainty;

The adoption of approaches based on experimentation, evaluation and monitoring;

The adoption of processes that foster continuous learning by stakeholders.
Participation of the various stakeholders, actors and society

In defining the vision;

In identifying problems and defining scenarios;

In defining objectives (strategic and operational), goals, strategies and measures;

In implementing the plan (strategies and measures).
Collaboration between institutions (public, private, NGOs), stakeholders/users and society:

To ensure establishing partnerships for

developing and implementing plans and policies;

To create diverse institutional arrangements and stakeholder-led as opposed to centralised, rigid and sector-specific management approaches,

To ensure multi-level governance and sharing of responsibilities between stakeholders.

FIGURE 1 | Principles of governance to be followed in marine planning and management (modified and expanded from Carvalho and Fidélis (2013).

relevant stakeholders are may vary, for example, when number of experts on the MSFD were asked "who are stakeholders of the MSFD?" in the context of the DEVOTES research project, the greatest number of answers were influencers, mainly from the sub-category of researchers and academics. Whole sectors, such as maritime transport were omitted. There were also large disparities according to the Member States, some mainly included regulators and influencers. Weightings may be also be attributed to stakeholders, and an illustrative example is given in Table 5, but it is not prescriptive.

The three steps above $(a, b, c)$ are part of the System Approach Framework (SAF) methodology, a step-wise approach to transdiciplinary co-design of management plans, (Newton, 2012). In addition, a methodology for successful stakeholder involvement and the design of participatory processes involves assessing what level of engagement is required. Participation is a way of engaging decision makers and approaches vary. It is important to consider distinctions between wishing to inform, learn from or collaborate with stakeholders and to evaluate what is appropriate in particular contexts. Furthermore, it is important to assess resource commitments within any engagement process and technique. For example, will the engagement be only via online questionnaires or will there be frequent face-to-face meetings? What is practically achievable in a given context is hugely dependent on available resources: money, time, and skills.

\section{Scoping}

At this stage the focus shifts from planning to recruitment of the stakeholders for the implementation of the participatory process. The engagement process should be designed to be appealing, to draw the stakeholders in an engaging manner and to convince them to remain involved throughout the process. The stakeholders should feel that their opinion is being sought and heard by the decision-makers included in the forum, especially when the participatory process is statutory. Particular effort should be made to engage relevant stakeholders of each type, which may require persistence. The invitation to participate should highlight that the contact is being made because they are regarded as a significant stakeholder whose opinion should be considered. Scoping is a defined term within the EIA legislation and requires stakeholders (at least "statutory consultees", such as regulatory bodies, but also "non-statutory-consultees" such as 
environmental NGOs) to indicate the main areas of concern, which can then be rigorously addressed. There are several considerations regarding barriers to involvement that need to be overcome, as well as issues of good conduct during the consultation.

At this point, it is also valuable to ask the stakeholders to respond to a very brief questionnaire. This should be structured with care, to establish whether the stakeholders are informed about the general issue (e.g., the implementation of the MSFD), and the specific issue (e.g., Descriptor 1, Marine Biodiversity). It should also allow the first version of the conflict matrix to be drafted, and ask for any suggestions for other possible stakeholders. This item allows identifying stakeholders that may have been missed, but also allows the mapping of stakeholder groups and networks. If the stakeholders do not respond to the questionnaire, a second invitation is an opportunity to reiterate that their participation is considered important. It is unlikely that a stakeholder who will not respond to a short questionnaire will participate actively in the stakeholder forum. However, the invitation should be kept open and reiterated, so that stakeholders may join at a later stage. Nevertheless, it should be emphasized to the stakeholders that this is a process that requires sustained participation and jumping in at the end to try to halt the process and acting as a "spoiler" is not an option.

\section{Establish the Stakeholder Forum}

The stakeholder forum (SF) members should be:

(i) Balanced across the different types of stakeholder (Table 2).

(ii) Relevant (Table 3) in the context of the issue definition (Section 6a) and the system definition (Section 6b).

(iii) Representative of a group of stakeholders (e.g., a fisher association), rather than individuals (a fisher; e.g., Table 4).

(iv) Significant (Table 5).

(v) Informed about both the over-arching issue (e.g., MSFD implementation) and the specific issue (e.g., Eutrophication; Section 6d).

(vi) Participative and responsive (Section 6d).

An example list of stakeholders for a Member State (UK) and marine region (North Sea) is given in Table 4.

\section{Briefing of the Stakeholder Forum Members and Their Meetings}

The level of engagement and commitment partly depends on the invitation to participate and the convivial atmosphere of the meetings. To keep stakeholders interested and engaged, they must be well-briefed at the start and kept well-informed of the steps and developments of the process. The Stakeholder Forum (SF) members should be briefed about the general aim (e.g., contribute to the implementation of the MSFD); the context (e.g., in the Baltic Sea); the specific issue (e.g., Descriptor 5, Eutrophication); their role (e.g., contribute expert opinion); the remit that may include the desired final outcome (e.g., establish a long-standing forum) and output (e.g., a Report of recommendations to HELCOM). An experienced and wellinformed convener will clarify any questions that may arise, particularly about the legitimacy of other members of the forum.
The meetings should be convened sufficiently far in advance to allow busy members of the Stakeholder Forum to attend. Once more, the meeting should be chaired by an experienced and well-informed convener and moderator, with the necessary skills to maintain a balanced debate, so that the views of all participants are heard. Minutes of the meeting, and especially any decisions, should be circulated to ensure that they reflect all points of view and retained for future cross-checking. Tasks and action points should be revised and reviewed at the beginning of each meeting. If the group is large, it may be useful to divide into subgroups, ensuring that there is a balance across the types and that each group has a moderator, and also to avoid groups containing "networks" (Section 6d). There are many existing conflict-resolution methods and tools (Section What Are the Difficulties and Conflicts and How Can They Be Resolved?) that can be used to reach consensus.

\section{Drafting the Report of Recommendations}

First of all it is important to identify appropriate choices from the range that are potentially available to decision makers. It is important to match the choice of the recommended technique to the purpose, and to understand what it will deliver, and what are the limitations. Once a consensus has been reached about the structure of the recommendations and the structure of the report, each stakeholder should be invited to contribute to sections for which their expertise is relevant. If they decline to do so, they may then be invited to review these sections. The lead author or editor of the report will invite and compile contributions and circulate the draft to the Stakeholder Forum for comments. Usually there are several iterations: the outline, the first draft, the second draft, the final draft and the pre-print or pre-submission proofs.

\section{Evaluate the Process and Its Outcomes}

There are different ways of evaluating the success of a participatory process. An important distinction exists between process success and outcome success. The outcome success is short-term, it addresses the issue that was analyzed. A longlasting success is achieved when the process was so wellconducted that a robust stakeholder forum continues to exist after the short-term issue has been resolved. This can result from a successfully run participatory process, where stakeholders become a supportive network of colleagues, allies and in some cases friends. It is emphasized that, for example, in an EIA the process not only has to be carried out but it has to be seen to be carried out.

\section{CONCLUDING REMARKS}

If we are now in the Anthropocene (Crutzen and Stoermer, 2000) and exceeding our planetary boundaries (Rockström et al., 2009; Steffen et al., 2015) there is an urgent need for future earth sustainability (Future Earth, 2014) to deliver on the promise of science for society. This entails "transdisciplinary" research that includes both science-society and science-policy, interfacing throughout the whole research process, from codesign of research to co-production of knowledge. Such a process inevitably relies for success on genuine and successful 
stakeholder engagement in truly participatory processes. This paper outlines both a typology and a roadmap that may serve to make co-design and acceptance of solutions a reality.

\section{AUTHOR CONTRIBUTIONS}

The manuscript is the result of many discussions over several years between the co-authors. The "order" of authors was discussed and it was decided that AN would lead the article. However, many of the ideas and substantial material were contributed by $\mathrm{ME}$, as co-author. AN drafted the outline and most of the roadmap, while ME concentrated on the typology and many of the examples. AN contributed Box 1, Tables 1, 3, 5.

\section{REFERENCES}

Barnard, S., and Elliott, M. (2015). The 10-tenets of adaptive management and sustainability: an holistic framework for understanding and managing the socio-ecological system. Environ. Sci. Policy 51, 181-191. doi: 10.1016/j.envsci.2015.04.008

Bidleman, T. F., Atlas, E. L., Atkinson, R., Bonsang, B., Burns, K., Keene, W., et al. (1990). "The long-range transport of organic compounds," in The Long-Range Atmospheric Transport of Natural and Contaminant Substances, ed A. J. Knap (Dordrecht: Kluwer), 259-301.

Borja, Á., and Elliott, M. (2013). Marine monitoring during an economic crisis: the cure is worse than the disease. Mar. Pollut. Bull. 68, 1-3. doi: 10.1016/j.marpolbul.2013.01.041

Borja, A., Elliott, M., Andersen, J. H., Cardoso, A. C., Carstensen, J., Ferreira, J. G., et al. (2013). Good environmental status of marine ecosystems: what is it and how do we know when we have attained it? Mar. Pollut. Bull. 76, 16-27. doi: 10.1016/j.marpolbul.2013.08.042

Boyes, S. J., and Elliott, M. (2014). Marine legislation - the ultimate 'horrendogram': international law, european directives \& national implementation. Mar. Pollut. Bull. 86, 39-47. doi: 10.1016/j.marpolbul.2014.06.055

Boyes, S. J., and Elliott, M. (2015). The excessive complexity of national marine governance systems - has this decreased in England since the introduction of the Marine and Coastal Access Act 2009? Mar. Policy. 51, 57-65. doi: 10.1016/j.marpol.2014.07.019

Boyes, S. J., Elliott, M., Murillas-Maza, A., Papadopoulou, N., and Uyarra, M. C. (2016). Is existing legislation fit-for-purpose to achieve Good Environmental Status in European seas? Mar. Pollut. Bull. 111, 18-32. doi: 10.1016/j.marpolbul.2016.06.079

Carvalho, T. M., and Fidélis, T. (2013). The relevance of governance models for estuary management plans. Land Use Policy 34, 134-145. doi: 10.1016/j.landusepol.2013.02.007

Christie, N., Smyth, K., Barnes, R. A., and Elliott, M. (2014). Co-location of activities and designations: a means of solving or creating problems in marine spatial planning? Mar. Policy 43, 254-261. doi: 10.1016/j.marpol.2013.06.002

Cinnirella, S., Sardà, R., Suárez de Vivero, J., Brennan, R., Barausse, A., Icely, J., et al. (2014). Steps towards a shared governance response for achieving good environmental status in the mediterranean sea. Ecol. Soc. 19:47. doi: 10.5751/ES-07065-190447

Crutzen, P. J., and Stoermer, E. F. (2000). The 'Anthropocene'. Glob. Change Newslett. 41, 17-18. Available online at: http://www.igbp.net/download/18. 316f18321323470177580001401/1376383088452/NL41.pdf

Durham, E., Baker, H., Smith, M., Moore, E., and Morgan, V. (2014). The BiodivERsA Stakeholder Engagement Handbook. Paris: BiodivERsA.

Elliott, M. (2013). The 10-tenets for integrated, successful and sustainable marine management. Mar. Pollut. Bull. 74, 1-5. doi: 10.1016/j.marpolbul.2013.08.001

Elliott, M. (2014). Integrated marine science and management: wading through the morass. Mar. Pollut. Bull. 86, 1-4. doi: 10.1016/j.marpolbul.2014.07.026
ME contributed Box 2, Tables 4, 6 and Figure 1. Table 2 was the work of both authors. Both authors contributed to the revisions and these were submitted by AN.

\section{ACKNOWLEDGMENTS}

To SPICOSA, KnowSeas, VECTORS, and DEVOTES colleagues for helping us to form our views. This manuscript is a result of the DEVOTES (DEVelopment Of innovative Tools for understanding marine biodiversity and assessing good Environmental Status) project, funded by the European Union under the 7th Framework Programme, "The Ocean of Tomorrow" Theme (grant agreement no. 308392, http://www. devotes-project.eu).
EU (2008). Marine Strategy Framework Directive (2008/56/EC) European Parliament and the Council.

Fish, R., Burgess, J., Chilvers, J., Footitt, A., Haines-Young, R., Russel, D., et al. (2011). Participatory and Deliberative Techniques to Embed an Ecosystems Approach into Decision Making: An Introductory Guide. London: Defra Project Code: NR0124.

Future Earth (2014). Future Earth 2025 Vision. Paris: ICSU.

Gari, S. R., Newton, A., and Icely, J. D. (2015). A review of the application and evolution of the DPSIR framework with an emphasis on coastal social-ecological systems. Ocean Coast. Manag. 103, 63-67. doi: 10.1016/j.ocecoaman.2014.11.013

Glasson, J., Therivel, R., and Chadwick, A. (2011). Introduction to Environmental Impact Assessment. London: Routledge.

Goela, P. C., Newton, A., Cristina, S., and Fragoso, B. (2009). Water framework directive implementation: intercalibration exercise for biological quality elements - a case study for the South Coast of Portugal. J. Coast. Res. Suppl. 56, 1214-1218. Available online at: http://www.cerf-jcr.org/images/stories/1214. 1218_P.Goela_ICS2009.pdf

Jones, P. J. S. (2012). Marine protected areas in the UK: challenges in combining top-down and bottom-up approaches to governance. Environ. Conserv. 39, 248-258. doi: 10.1017/S0376892912000136

Lovens, A., Turkelboom, F., Demeyer, R., Garcia-Llorente, M., Hauck, J., Kelemen, E., et al. (2014). OpenNESS Manual: Stakeholder Analysis for Environmental Decision-Making at Local Level. Publication developed in the framework of OpenNESS (FP7 Project). Brussels: INBO.

Mehrizi, M. H. R., Ghasemzadeh, F., and Mollas-Gallart, J. (2009). Stakeholder mapping as an assessment framework for policy implementation. Evaluation 15, 427-444. doi: 10.1177/1356389009341731

Morris, J. (2012). Back to Basics: How to Make Stakeholder Engagement Meaningful for Your Company. New York, NY: BSR.

Natural England and the Joint Nature Conservation Committee (2012). A Stakeholder-Led Process - How were Sea Users and Other Interest Groups Involved in Recommending Marine Conservation Zones? Peterborough: Natural England and the Joint Nature Conservation Committee.

Newton, A. (2012). A Systems approach for sustainable development in coastal zones. Ecol. Soc. 17:41. doi: 10.5751/ES-04711-170341

Ostrom, E. (2009). A general framework for analyzing sustainability of socialecological systems. Science 325, 419-422. doi: 10.1126/science.1172133

Pacyna, E. G., Pacyna, J. M., Steenhuisen, F., and Wilson, S. (2006). Global anthropogenic mercury emission inventory for 2000. Atmos. Environ. 40, 4048-4063. doi: 10.1016/j.atmosenv.2006.03.041

Patrício, J., Elliott, M., Mazik, K., Papadopoulou, K.-N., and Smith, C. J. (2016). DPSIR-Two decades of trying to develop a unifying framework for marine environmental management? Front. Mar. Sci. 3:177. doi: 10.3389/fmars.2016.00177

Rabalais, N. N., Turner, R. E., and Wiseman, W. J. Jr. (2002). Gulf of Mexico Hypoxia, A.K.A. "The Dead Zone". Ann. Rev. Ecol. Syst. 33, 235-263. doi: 10.1146/annurev.ecolsys.33.010802.150513 
Rockström, J., Steffen, W., Noone, K., Persson, Å., Chapin, F. S., III, Lambin, E. F., et al. (2009). A safe operating space for humanity. Nature 461, 472-475. doi: $10.1038 / 461472$ a

Scharin, H., Ericsdotter, S., Elliott, M., Turner, R. K., Niiranen, S., Rockström, J. et al. (2016). Processes for the sustainable stewardship of marine environments. Ecol. Econ. 128, 55-67. doi: 10.1016/j.ecolecon.2016.04.010

Semeoshenkova, V., and Newton, A. (2015). Overview of beach erosion and quality issues in three Southern European countries: Portugal, Spain and Italy. Ocean Coast. Manag. 118, 12-21. doi: 10.1016/j.ocecoaman.2015.08.013

Steffen, W., Richardson, K., Rockström, J., Cornell, S. E., Fetzer, I., Bennett, E. M. et al. (2015). Planetary boundaries: guiding human development on a changing planet. Science 347:1259855. doi: 10.1126/science. 1259855

Weber, M. (1991). "The nature of social action," in Weber: Selections in Translation, ed W. G. Runciman (Cambridge: Cambridge University Press), 7-32.

World Meteorological Organization (WMO) (2006). Social Aspects and Stakeholder Involvement in Integrated Flood Management. APFM Technical
Document No. 4, Flood Management Policy Series. ISBN: 92-63-11008-5. Geneva, Switzerland. p. 100.

Conflict of Interest Statement: The authors declare that the research was conducted in the absence of any commercial or financial relationships that could be construed as a potential conflict of interest.

The handling Editor declared a collaboration with the authors and states that the process nevertheless met the standards of a fair and objective review.

Copyright $\odot 2016$ Newton and Elliott. This is an open-access article distributed under the terms of the Creative Commons Attribution License (CC BY). The use, distribution or reproduction in other forums is permitted, provided the original author(s) or licensor are credited and that the original publication in this journal is cited, in accordance with accepted academic practice. No use, distribution or reproduction is permitted which does not comply with these terms. 